\title{
Escherichia coli Hemolysin Is a Potent Inductor of Phosphoinositide Hydrolysis and Related Metabolic Responses in Human Neutrophils
}

\author{
Friedrich Grimminger, Ulf Sibelius, Sucharit Bhakdi, * Norbert Suttorp, and Werner Seeger \\ Department of Internal Medicine, Justus Liebig University, Giessen, D-6300 Federal Republic of Germany; and *Institute of Medical \\ Microbiology, Gutenberg University, Mainz, D-6500 Federal Republic of Germany
}

\begin{abstract}
Escherichia coli hemolysin (Hly) is a proteinaceous pore-forming exotoxin that probably represents a significant virulence factor in $E$. coli infections. We investigated its influence on human polymorphonuclear neutrophils (PMN), previously identified as highly susceptible targets. Hly provoked rapid secretion of elastase and myeloperoxidase, generation of superoxide, and synthesis of platelet-activating factor (PAF) and lyso-PAF. Concomitantly, marked phosphatidylinositol (PtdIns) hydrolysis with sequential appearance of the inositolphosphates, inositol triphosphate, diphosphate, and monophosphate, respectively, and formation of diacylglycerol, occurred. The metabolic responses displayed distinct bell-shaped dose dependencies, with maximum events noted at low toxin concentrations of 0.1-0.5 hemolytic units per milliliter. PtdIns hydrolysis and metabolic responses elicited by Hly exceeded those evoked by optimal concentrations of formylmethionyl-leucyl phenylalanine, PAF, leukotriene $B_{4}, \mathbf{A 2 3 1 8 7}$, or staphylococcal $\alpha$-toxin. The toxin-induced effects were sensitive toward modulators of PMN stimulus transmission pathways (pertussis toxin, the kinase $\mathrm{C}$ inhibitor $\mathrm{H7}$, and phorbol myristate acetate "priming"). We conclude that the marked capacity of low doses of Hly to elicit degranulation, respiratory burst, and lipid mediator generation in human PMN probably envolves signal transduction via PtdIns hydrolysis. (J. Clin. Invest. 1991. 88:1531-1539.) Key words: Escherichia coli hemolysin • neutrophil activation $\bullet$ phosphoinositide
\end{abstract}

\section{Introduction}

Certain strains of Escherichia coli produce a proteinaceous exotoxin, designated hemolysin (Hly), ${ }^{1}$ which was originally characterized by its lytic effect on erythrocytes (1-4). Secretion of active Hly requires the expression of four genes (hlyA, hlyB, hlyC, hlyD), constituting the hly operon $(5,6)$. The hlyA gene

Address reprint requests to Dr. Grimminger, Department of Internal Medicine, Justus-Liebig-Universität Giessen, D-6300 Giessen, Federal Republic of Germany. 1991.

Received for publication 28 March 1991 and in revised form 8 July

1. Abbreviations used in this paper: DAG, diacylglycerol; GPC, glycerophosphorylcholine; Hly, Escherichia coli hemolysin; HU, hemolytic unit(s); $I_{1}, I_{2}$, and $I_{P_{3}}$, inositol monophosphate, diphosphate, and triphosphate, respectively; LDH, lactate dehydrogenase; PAF, plateletactivating factor; PT, pertussis toxin; PtdIns, phosphatidylinositols.

J. Clin. Invest.

(c) The American Society for Clinical Investigation, Inc.

0021-9738/91/11/1531/09 $\$ 2.00$

Volume 88, November 1991, 1531-1539 encodes the $110-\mathrm{kD}$ hemolysin protein, which is activated by the hlyC gene product. Secretion of HlyA occurs via a transport mechanism involving the HlyB and HlyD proteins. Approximately $50 \%$ of $E$. coli isolates causing extraintestinal infections in humans produce Hly; this agent represents one of the most prevalent bacterial exotoxins encountered in humans $(1,3,4$, 7-9). Its pathogenetic relevance has been established in animal models with the use of genetically engineered bacterial strains $(1,7,10)$. An analogous role in human infections has been inferred from the high association of hemolysin production with disease, including pyelonephritis and septicemia $(8,9)$.

The primary structure of Hly has been deduced from the nucleotide sequence (11). Several cytotoxins elaborated by other gram-negative rods including Morganella morganii, Proteus spp., and Pasteurella haemolytica exhibit structural and functional similarities to $\mathrm{Hly}$, indicating that these proteins constitute a new family of pore-forming toxins (12-16). The membrane permeabilizing capacities of Hly have been demonstrated in erythrocytes, neutrophils (PMN), monocytes, endothelial cells, and artificial lipid bilayers (2, 17-22). A high-affinity calcium binding domain, required for toxin membrane insertion, has been disclosed (22-24).

Although basically endowed with the capacity to permeabilize a large variety of target cells, Hly exerts a particularly potent action on granulocytes $(20,25,26)$. Release of elastase and other granule constituents and loss of phagocytic killing capacity were observed upon exposure of PMN to Hly concentrations far below those causing erythrocyte lysis. In a recent study, we showed that subhemolytic doses of the toxin induce marked leukotriene (LT) generation in human neutrophils (27). In the present investigation, we sought to determine whether low-dose effects of Hly on neutrophils might be related to phosphatidylinositol (PtdIns) hydrolysis, which serves as major signal transduction pathway in PMN challenged with ligands such as lipid (leukotriene $\mathrm{B}_{\mathbf{4}}\left[\mathrm{LTB}_{4}\right]$ and platelet-activating factor [PAF]) and peptide chemoattractants (formylmethionyl-leucyl-phenylalanine [FMLP]) (28-32). Inositol phosphate and diacylglycerol (DAG) formation was found to parallel degranulation, respiratory burst, and lipid mediator generation in Hly-treated PMN. Indeed, when compared to FMLP, PAF, $\mathrm{LTB}_{4}$, and A23187, Hly emerged as the most potent inductor of PtdIns hydrolysis hitherto described.

\section{Methods}

Materials. FMLP, 1-O-hexadecyl-2-acetyl-sn-glycero-3-phosphocholine (PAF), superoxide dismutase, cytochrome $c$ type IV, diethylenetriaminepentaacetic acid, Hepes, phorbol myristate acetate (PMA), and phospholipids were obtained from Sigma Chemical Co. (Deisenhofen, FRG); octyl- $\beta$-D-glucoside from Behring Diagnostics (Frankfurt, FRG). LT $B_{4}$ was purchased from Paesel AG (Frankfurt, FRG), purified by high-pressure liquid chromatography (HPLC), and quantified before use as described $(33,34)$. The PAF receptor antagonist 
WEB 2086 was generously supplied by Boehringer (Ingelheim, FRG), and the 5-lipoxygenase inhibitor L-663-536 was a kind gift from Dr. C. Rouzer; Merck Frosst (Canada). Highly purified Bordetella pertussis toxin (PT) as well as its inactive $B$ oligomer and the kinase $C$ inhibitor 1-(5-isoquinolinesulfonyl)-2-methylpiperazine (H7) were purchased from Calbiochem-Behring Corp. (La Jolla, CA). Diglyceride kinase was obtained from Lipidex, Inc. (Middleton, WI). [ $\left.\gamma-{ }^{32} \mathrm{P}\right] A$ TP (sp act 4,500 $\mathrm{Ci} / \mathrm{mmol}$ ) was from ICN Radiochemicals (Irvine CA), and S-2484, a chromogenic substrate for granulocyte elastase, from Kabi-Vitrum (Stockholm, Sweden). RPMI 1640 medium, medium 199, Hanks' balanced salt solution, and fetal calf serum were from Gibco Laboratories (Grand Island, NY), and Percoll was from Pharmacia Fine Chemicals (Uppsala, Sweden). Tritiated inositol phosphates, $\left[{ }^{3} \mathrm{H}\right] \mathrm{PAF},\left[{ }^{3} \mathrm{H}\right]$ lysoPAF, $\left[{ }^{3} \mathrm{H}\right]$ phosphatidylcholine, $\left[{ }^{14} \mathrm{C}\right]$ phosphatidic acid, and $\left[{ }^{3} \mathrm{H}\right]$ serotonin were obtained from Amersham Corp. (Dreieich, FRG). Myo-[2${ }^{3} \mathrm{H}$ ]inositol was purchased from New England Nuclear (Boston, MA). Chromatographic supplies included silica gel $5-\mu \mathrm{m}$ column packing (Machery Nagel, Düren, FRG), HPLC-grade solvents, distilled in glass (Fluka KG, Heidelberg, FRG), and silica gel $60 \mathrm{~F}_{254}$ plates (Merck \& Co., Darmstadt, FRG). All other biochemicals were obtained from Merck \& Co., (Munich, FRG).

Preparation of human granulocytes. Heparinized human donor blood was centrifuged in a discontinuous Percoll gradient (35) to yield a PMN fraction of $\sim 97 \%$ purity. Before experiments with measurement of granule secretion, superoxide production, PAF, or DAG synthesis, PMN were kept in RPMI 1640 medium with $10 \%$ calf serum for $2 \mathrm{~h}$. For analysis of phosphoinositide metabolism, preincubation with myo$\left[2{ }^{3} \mathrm{H}\right]$ inositol was carried out in medium 199 (Gibco Laboratories) with $2 \%$ calf serum for $2 \mathrm{~h}$. After cell washing, PT $(1.5 \mu \mathrm{g} / \mathrm{ml})$, its B oligomer $(1.3 \mu \mathrm{g} / \mathrm{ml})$, or a corresponding buffer volume were added, followed by another 2-h incubation period. Immediately before stimulus application, the cells were washed twice and suspended in Hanks' Hepes buffer. Cell viability, as assessed by trypan blue exclusion, ranged above $96 \%$ and lactate dehydrogenase (LDH) release was consistently below $3 \%$ at this time.

Preparation of $E$. coli hemolysin. The hemolysin was prepared as described $(2,36)$. The endotoxin content of the preparation was reduced to $\sim 3 \mathrm{ng}$ of lipopolysaccharide (LPS)/ $\mu \mathrm{g}$ protein. The hemolytic titer was assessed directly before use and expressed in hemolytic units $(\mathrm{HU}) / \mathrm{ml} ; 1 \mathrm{HU} / \mathrm{ml}$ corresponded to $\approx 100 \mathrm{ng}$ protein $/ \mathrm{ml}$. At the optimum Hly concentration used $(0.1 \mathrm{HU} / \mathrm{ml})$, endotoxin levels ranged between 25 and $35 \mathrm{pg} / \mathrm{ml}$ (assessed with Limulus lysate assay using chromogenic substrate, according to Friberger [37]).

Superoxide anion generation. $\mathrm{PMN}_{2}^{-}$generation was measured as superoxide dismutase inhibitable cytochrome $c$ reduction as described (38). Duplicate reaction mixtures containing $5 \times 10^{6} / \mathrm{ml} \mathrm{PMN} \mathrm{and} 75$ $\mu \mathrm{M}$ ferricytochrome $c$ were incubated for the indicated time intervals at $37^{\circ} \mathrm{C}$ in the presence or absence of $10 \mu \mathrm{g} / \mathrm{ml}$ superoxide dismutase. Incubations were terminated by centrifugation at $4^{\circ} \mathrm{C}$ for $5 \mathrm{~min}$ at $1,200 \mathrm{~g} . \mathrm{O}_{2}^{-}$production is expressed as nanomoles of cytochrome reduced, using an extinction coefficient of $21 \mathrm{mM}^{-1} \mathrm{~cm}^{-1}$ at $549 \mathrm{~nm}$.

Release of granule constituents and $L D H$. Elastase, myeloperoxidase, and LDH release were taken as markers for PMN degranulation and cell lysis, respectively, and were measured according to standard procedures $(39,40)$.

Measurement of $P A F$ precursor, $P A F$, and lyso-PAF in prelabeled cells. Metabolism of PAF was determined by stimulating neutrophils containing 1-O- $\left[{ }^{3} \mathrm{H}\right]$ alkyl-2-acyl-glycerophosphorylcholine (GPC), obtained by prelabeling the cells with $1-O-\left[^{3} \mathrm{H}\right]$ alkyl-2-lyso-GPC $(56 \mathrm{Ci} /$ mmol), using a modification of the method described by Chilton et al. (41). Briefly, PMN $\left(1 \times 10^{8}\right.$ cells $\left./ \mathrm{ml}\right)$ were incubated for $2 \mathrm{~h}$ with 100 $\mu \mathrm{Ci} / \mathrm{ml}\left[^{3} \mathrm{H}\right]$ lyso-PAF in RPMI $(10 \%$ calf serum) in a shaking water bath $\left(37^{\circ} \mathrm{C}\right)$. During this period, $95 \%$ of the radiolabel became cell associated with $85 \%$ of the label extractable as $1-O-\left[{ }^{3} \mathrm{H}\right]$ alkyl-2-acylGPC. Before stimulation, cells were washed twice and resuspended in Hanks' balanced salt solution $\left(1 \times 10^{7}\right.$ cells $\left./ \mathrm{ml}\right)$. Reactions were stopped by addition of three volumes of chloroform/methanol (2:1, vol/vol) and extracted according to Bligh and Dyer (42). The entire lipid extract was evaporated to dryness, redissolved in $60 \mu \mathrm{l}$ of the mobile phase, and subjected to straight-phase HPLC separation. The column $(25 \times 0.46 \mathrm{~cm})$ was packed with silica gel $5-\mu \mathrm{m}$ particles and eluted isocratically with acetonitrile/methanol/phosphoric acid $(95.5: 3.5: 1)$ at a flow rate of $1.8 \mathrm{ml} / \mathrm{min}$. Eluate fractions corresponding to appropriate standard retention times were collected and assayed for radioactivity by liquid scintillation counting. In selected experiments, the elution of radiolabel was monitored using a radiochromatogram imaging system (5LS Raytest). In additional studies, PAF synthesis was quantified by incorporation of labeled acetate. $10^{7} \mathrm{PMN}$ were stimulated in the presence of $50 \mu \mathrm{Ci}\left[{ }^{3} \mathrm{H}\right]$ acetate $(7.75 \mathrm{Ci} / \mathrm{mmol})$ in a total volume of $1 \mathrm{ml}$ according to Tessner et al. (43). Extraction and HPLC processing were performed as indicated above. Up to $0.6 \%$ of the exogenously offered $\left[{ }^{3} \mathrm{H}\right]$ acetate was incorporated into total lipid fraction during this procedure.

Post-HPLC PAF bioassay. PAF production in nonlabeled PMN was quantified by induction of $\left[{ }^{3} \mathrm{H}\right]$ serotonin release from prelabeled rabbit platelets. After termination of PMN incubation, the total cellular and extracellular PAF content was lipid-extracted and subjected to HPLC separation as indicated above. Eluate fractions were collected at the appropriate PAF retention time, again lipid-extracted for removal of phosphoric acid present in the mobile phase, evaporated to dryness, and redissolved in $50 \mu \mathrm{l}$ of assay buffer for induction of platelet serotonin release. Preparation of platelets and the protocol of the bioassay were essentially as published by Pinkard et al. (44). $\left[{ }^{3} \mathrm{H}\right]$ serotoninlabeled platelets $(250,000$ cells $/ \mu \mathrm{l}$ in a total volume of $0.5 \mathrm{ml})$ were incubated for $60 \mathrm{~s}$. A $200-\mu \mathrm{l}$ aliquot then was rapidly removed, added to a chilled tube containing $20 \mu \mathrm{l}$ of $1.5 \mathrm{mM}$ formaldehyde, and centrifuged at $12,000 \mathrm{~g}$ for $2 \mathrm{~min}$. The serotonin secretion into the platelet supernatant was determined by liquid scintillation counting and related to that released from the same volume of platelet suspension after cell lysis with Triton X-100 (final concentration $0.83 \%$ wt/vol). Known quantities of PAF were used to establish a calibration curve for the bioassay. Aliquots of each sample were used to ascertain the specificity of platelet secretion by the inhibitory effect of the PAF receptor antagonist WEB $2086(1 \mu \mathrm{M})$.

Phosphoinositide metabolism. The PtdIns turnover of stimulated neutrophils was investigated by measuring the accumulation of inositol phosphates according to Berridge et al. (45). For prelabeling of cellular phospholipid pools, PMN were resuspended to $1 \times 10^{8}$ cells $/ \mathrm{ml}$ with medium 199 containing $2 \%$ fetal calf serum plus $40 \mathrm{mM}$ Hepes buffer, pH 7.4. Myo- $\left[{ }^{3} \mathrm{H}\right]$ inositol $(50 \mu \mathrm{Ci} / \mathrm{ml})$ was added, and cells were incubated at $37^{\circ} \mathrm{C}$ for $2 \mathrm{~h}$ on a shaking water bath. Before experimental use, cells were washed twice and resuspended in Hanks' balanced salt solution containing $20 \mathrm{mM}$ Hepes and $10 \mathrm{mM} \mathrm{LiCl}\left(1 \times 10^{7} \mathrm{PMN} / \mathrm{ml}\right)$. At different times after stimulus application, samples were quenched with trichloroacetic acid (final concentration 7.5\%), kept on ice for $15 \mathrm{~min}$, and extracted four times with diethylether. The aqueous phase was

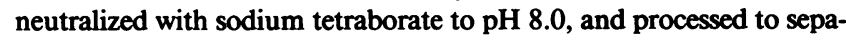
rate inositol phosphates on Dowex anion exchange columns as described by Berridge et al. (45). The column was eluted sequentially with water (for free $\left[{ }^{3} \mathrm{H}\right]$ inositol); $5 \mathrm{mM} \mathrm{Na}$-tetraborate $/ 60 \mathrm{mM} \mathrm{Na}$-formate (for glycerophospho- $\left[{ }^{3} \mathrm{H}\right]$ inositol); $0.1 \mathrm{M}$ formic acid/0.2 M ammonium formate (for $\left[{ }^{3} \mathrm{H}\right]$ inositol monophosphate $\left[\mathrm{IP}_{1}\right] ; 0.1 \mathrm{M}$ formic acid/0.5 M ammonium formate (for $\left[{ }^{3} \mathrm{H}\right]$ inositol diphosphate $\left[\mathrm{IP}_{2}\right]$ ); $0.1 \mathrm{M}$ formic acid/1.0 M ammonium formate (for $\left[{ }^{3} \mathrm{H}\right]$ inositol triphosphate $\left[\mathrm{IP}_{3}\right]$; and samples were processed for liquid scintillation counting.

$D A G$ assay. 0.8-ml samples of $\mathrm{PMN}$ suspension $\left(1 \times 10^{7}\right.$ cells $\left./ \mathrm{ml}\right)$ were mixed with $3 \mathrm{ml}$ of chloroform/methanol with subsequent splitting of the monophase by addition of chloroform and $1 \mathrm{M} \mathrm{NaCl}(1 \mathrm{ml}$ each) according to Bligh and Dyer (42). The chloroform phase was removed, kept at $-20^{\circ} \mathrm{C}$ to minimize acyl group migration and DAG was quantified within $24 \mathrm{~h}$ by enzymatic conversion to [ ${ }^{32} \mathrm{P}$ ]phosphatidic as described (46). Briefly, an aliquot of the chloroform phase was evaporated under nitrogen, and the lipid film solubilized in $20 \mu \mathrm{l}$ of $7.5 \%$ octyl- $\beta$-D-glucoside, $5 \mathrm{mM}$ cardiolipin, $1 \mathrm{mM}$ diethylenetriaminepentaacetic acid by water bath sonication. The resulting mi- 
celles were then reacted with $E$. coli sn-1,2-DAG kinase in the presence of $5 \mathrm{mM}\left[\gamma-{ }^{32} \mathrm{P}\right] \mathrm{ATP}$. After subsequent neutral lipid extraction, an aliquot of the lipid phase was subjected to thin-layer chromatography on a Silica gel $60 \mathrm{~F}_{254}$ plate and developed with chloroform/methanol/ acetic acid $(65: 15: 5, \mathrm{vol} / \mathrm{vol} / \mathrm{vol})$. Identification of DAG and its separation from labeled ceramide phosphate was ascertained by autoradiography before liquid scintillation counting of the DAG spot. Samples of sn-1,2-diolein were carried through the same procedure and spotted onto each plate as controls. Thereby, DAG recovery and conversion were ascertained to range consistently above $85 \%$. The amounts of $s n-1,2-D A G$ present in the original samples were calculated from the respective phosphatidic acid counts and the specific activity of the adenosine triphosphate (ATP) batch employed.

\section{Results}

Incubation of human neutrophils with Hly caused a rapid, dose-dependent secretion of elastase (Fig. 1). This response commenced at toxin doses below $0.1 \mathrm{HU} / \mathrm{ml}$ and reached its maximum at $0.5-2.5 \mathrm{HU} / \mathrm{ml}$. At these concentrations, elastase liberation surpassed that elicited by optimum concentrations of established receptor-operated stimuli, the $\mathrm{Ca}^{++}$ionophore

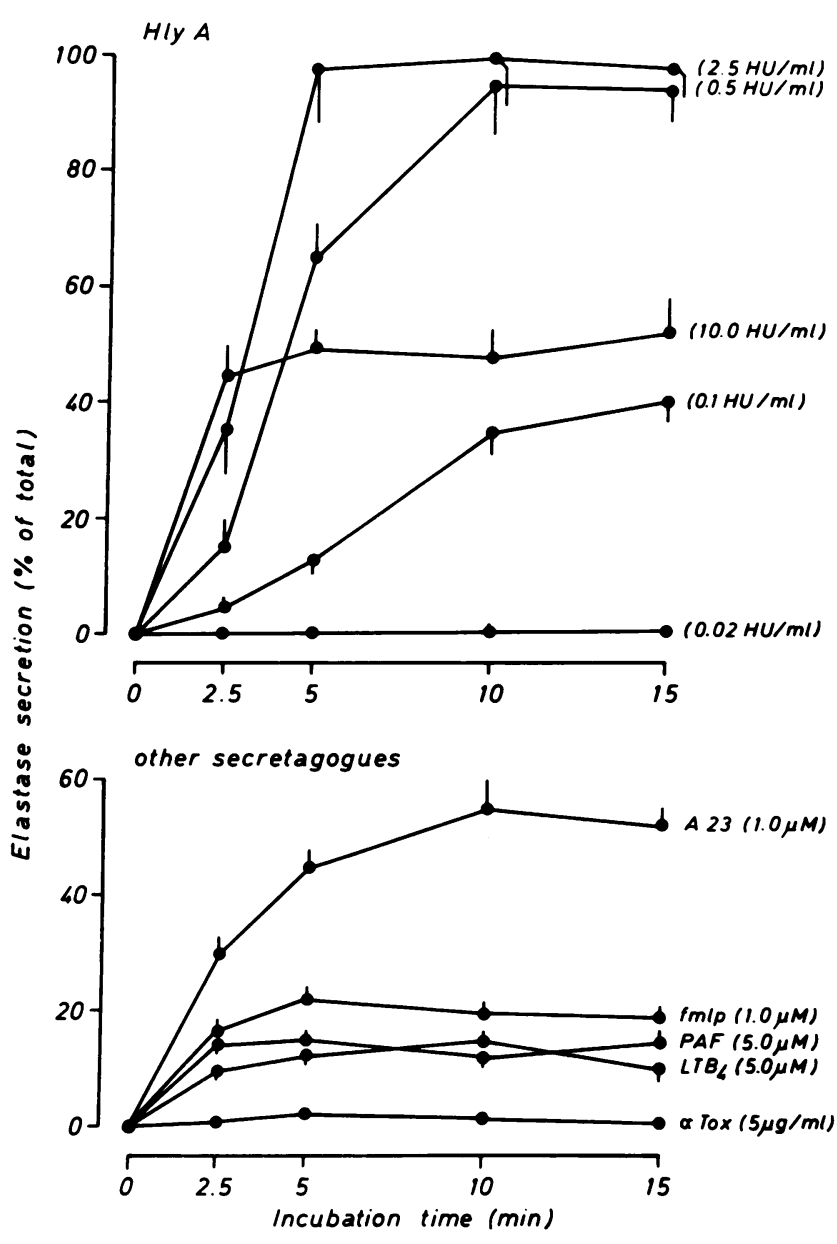

Figure 1. Time course of neutrophil elastase secretion evoked by Hly in comparison with different other secretagogues. $10^{7} \mathrm{PMN}$ were incubated with different concentrations of Hly (top) or different other secretagogues at optimum concentrations (bottom) for various time periods. Elastase release is expressed as percentage of total cellular amount. Means \pm SEM of five (top) and four (bottom) independent experiments are given.

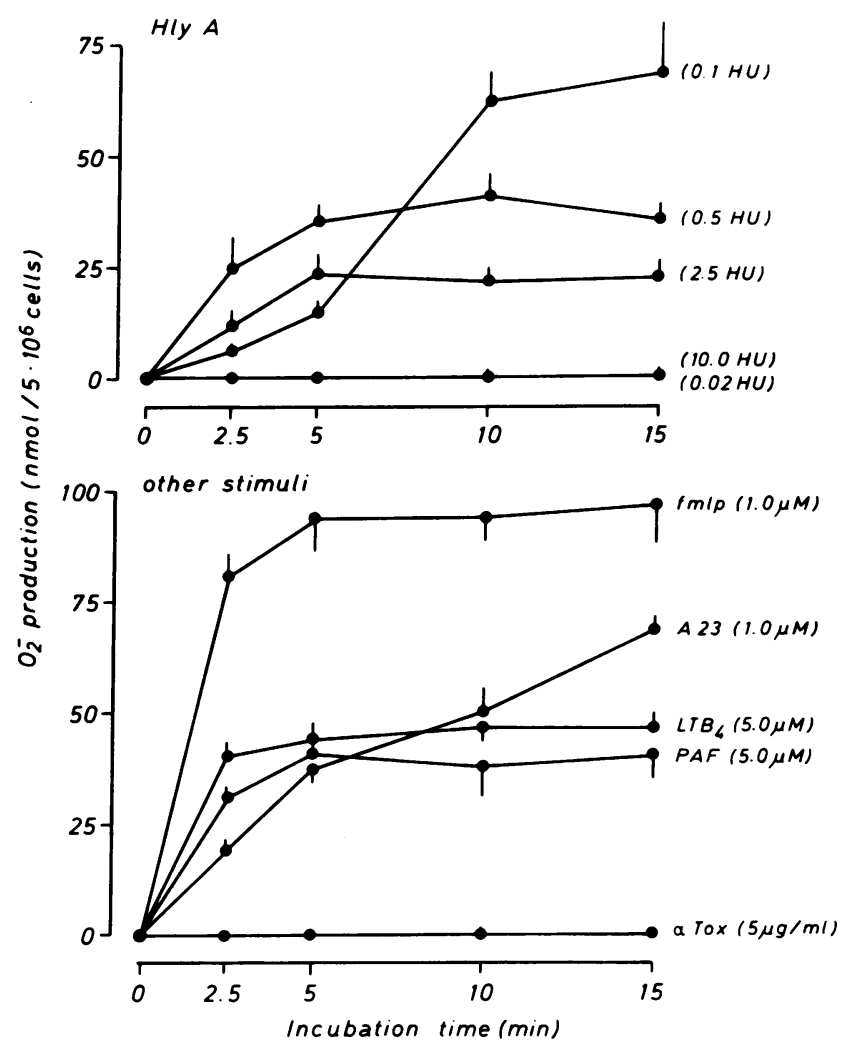

Figure 2. Time course of neutrophil superoxide production evoked by Hly in comparison with different other stimuli. $10^{7} \mathrm{PMN}$ were incubated with different concentrations of Hly (top) or different other stimuli at optimum concentrations (bottom) for various time periods. Means \pm SEM of five (top) and four (bottom) independent experiments are given.

A23187 and the pore-forming staphylococcal $\alpha$-toxin by 2 - to $>10$-fold. At higher Hly doses $(10 \mathrm{HU} / \mathrm{ml}$, Fig. 1$)$, there was a rapid onset but somewhat reduced extent of elastase secretion. In addition, toxin-treated neutrophils released myeloperoxidase with similar dose and time dependencies (data not shown).

Respiratory burst, measured as $\mathrm{O}_{2}^{-}$release, was also noted in Hly-treated PMN. This response was maximal at very low Hly doses $(\approx 0.1 \mathrm{HU} / \mathrm{ml}$; Fig. 2$)$; at $10 \mathrm{HU} / \mathrm{ml}$, no $\mathrm{O}_{2}^{-}$release was detected. The magnitude of the toxin-evoked $\mathrm{O}_{2}^{-}$liberation was in the range of that elicited by optimum concentrations of PAF, $\mathrm{LTB}_{4}, \mathrm{~A}_{23187 \text {, and FMLP. }}$

Analysis of liberated and cell-bound PAF by post-HPLC bioassay and $\left[{ }^{3} \mathrm{H}\right]$ acetate and $\left[{ }^{3} \mathrm{H}\right]$ lyso-PAF bioincorporation revealed marked formation of this lipid mediator in response to Hly challenge (Figs. 3 and 4). Maximum amounts of PAF were elicited by $0.1-0.5 \mathrm{HU} / \mathrm{ml}$ of the toxin. PAF liberation was paralleled by the appearance of lyso-PAF in similar amounts in all experiments.

Neutrophil activation with Hly caused rapid-onset, sustained PtdIns hydrolysis with sequential appearance of the inositol phosphates $\mathrm{IP}_{3}$ and $\mathrm{IP}_{2}$ and accumulation of $\mathrm{IP}_{1}$ (Figs. 5 and 6). Maximum responses were again elicited by $0.1-0.5$ $\mathrm{HU} / \mathrm{ml}$. Total amounts of liberated inositol phosphates surpassed those evoked by optimum concentrations of the receptor-operated stimuli PAF, FMLP, and $\mathrm{LTB}_{4}$ and of A23187 and $\alpha$-toxin by greater than twofold. Correspondingly, marked 


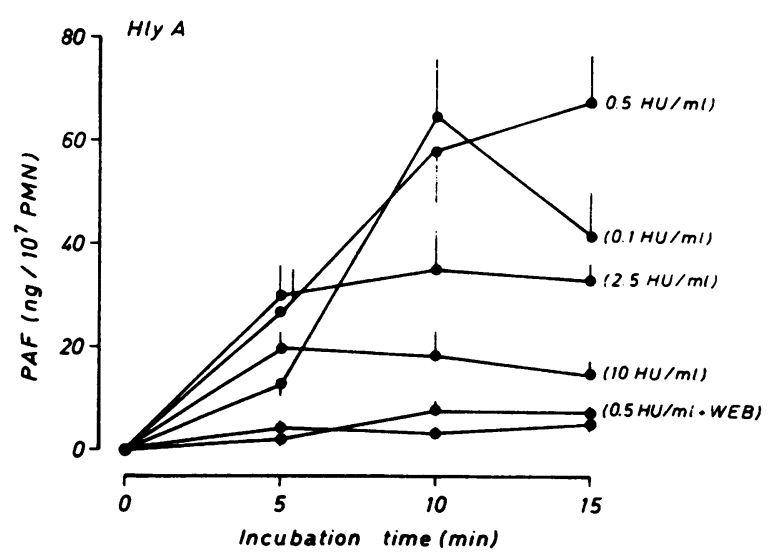

Figure 3. Time course of neutrophil PAF generation in response to Hly challenge. $10^{7} \mathrm{PMN}$ were incubated with different concentrations of Hly for various time periods. Secreted and cell-bound PAF was lipid-extracted, purified by HPLC, and quantified by induction of $\left[{ }^{3} \mathrm{H}\right]$ serotonin release from prelabeled platelets. Specificity of the platelet release reaction was ascertained by use of the PAF antagonist WEB 2086 (indicated for $0.5 \mathrm{HU} / \mathrm{ml}$ in the figure). Means \pm SEM of five (top) and four (bottom) independent experiments are given. generation of DAG was detectable in Hly-exposed PMN, exceeding the amount of this second messenger in FMLP-treated cells by about threefold (Fig. 7).

In the concentration range used, Hly incubation evoked only moderate, protracted LDH release as a marker of overt cell lysis (Fig. 8). At $\leq 0.5 \mathrm{HU} / \mathrm{ml}$, only $\approx 3-5 \%$ of total PMN LDH was liberated within $15 \mathrm{~min}$ of toxin challenge. LDH release amounted to $>15 \%$ within the same incubation time in the presence of $10 \mathrm{HU} / \mathrm{ml}$.

In PMN pretreated with PT, Hly-evoked PtdIns hydrolysis and elastase secretion were significantly inhibited (Table I). The PT sensitivity was inversely related to the Hly dose. The extent of suppression effected by PT was slightly lower as compared to FMLP-, PAF-, and $\mathrm{LTB}_{4}$-stimulated neutrophils. In control experiments, equal amounts of the inactive $B$ oligomer of PT did not inhibit Hly-, FMLP-, or lipid mediator-evoked cellular events. As anticipated, PMN activation elicited by the ionophore was not significantly inhibited by PT.

In the presence of the protein kinase $\mathrm{C}$ inhibitor $\mathrm{H} 7$, the Hly-evoked oxygen burst was reduced to $<50 \%$, whereas elastase liberation and inositol phosphate accumulation were not significantly affected (Table II). The PAF antagonist

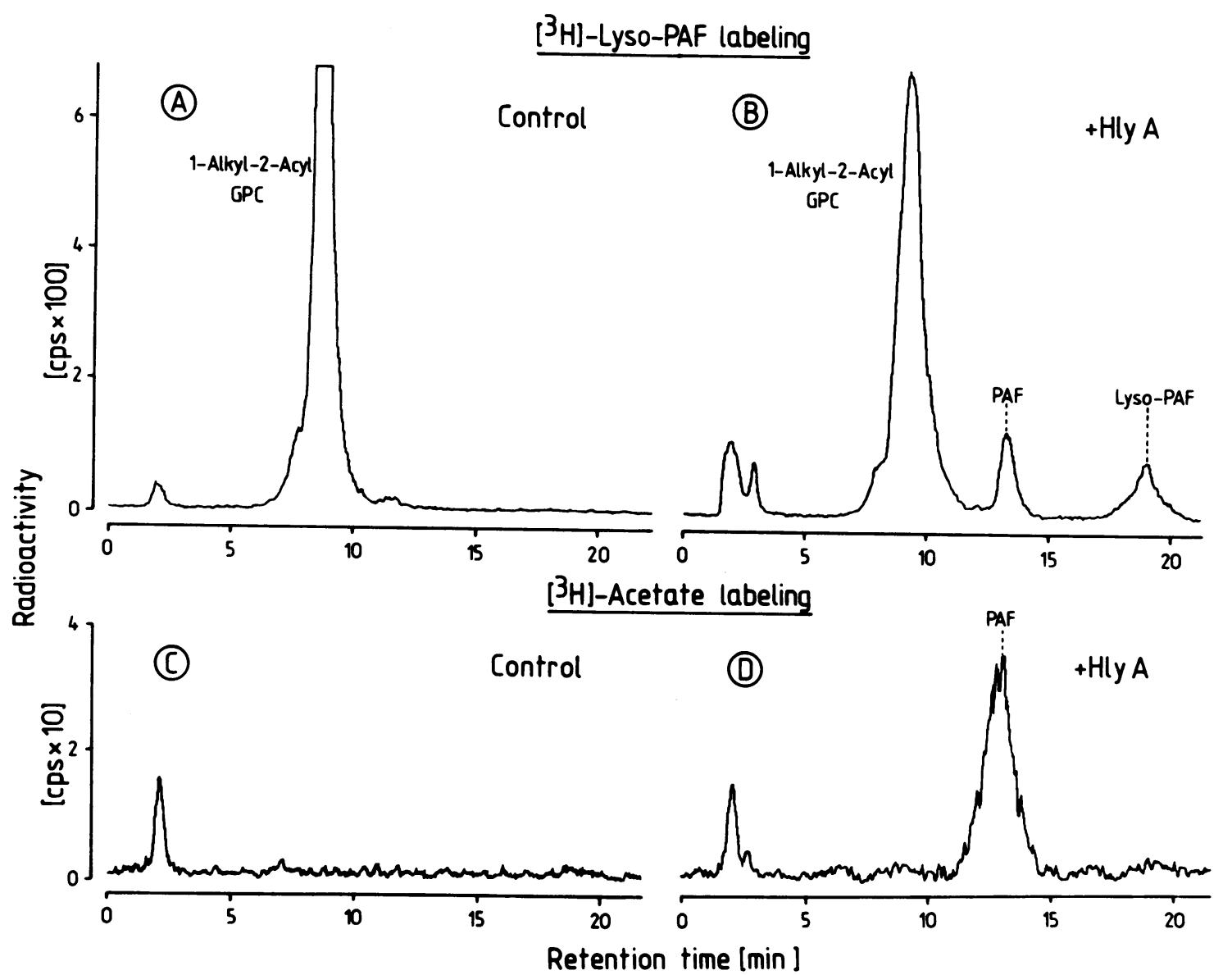

Figure 4. Analysis of PAF generation in Hly-challenged neutrophils by bioincorporation of labeled lyso-PAF and acetate. $10^{7} \mathrm{PMN}$ were preincubated with $\left[{ }^{3} \mathrm{H}\right]$ lyso-PAF $(1 \mathrm{~h} ; A$ and $B)$ or $\left[{ }^{3} \mathrm{H}\right]$ acetate $(30 \mathrm{~s} ; C$ and $D)$ before application of $0.1 \mathrm{HU} / \mathrm{ml} \mathrm{Hly}(B$ and $D)$ or sham challenge $(A$ and $C$ ). Lipid-extracted radioactivity was separated by SP-HPLC as detailed in Methods. In quiescent PMN, only labeled phophatidylcholine (GPC) was detected upon lyso-PAF preincubation. In response to Hly challenge (10 min), the labeled phosphatidylcholine pool decreased concomitant with the appearance of PAF and lyso-PAF. Correspondingly, $\left[{ }^{3} \mathrm{H}\right]$ acetate incorporation into the PAF fraction was detected in these cells. Data from one representative experiment out of five are shown. 


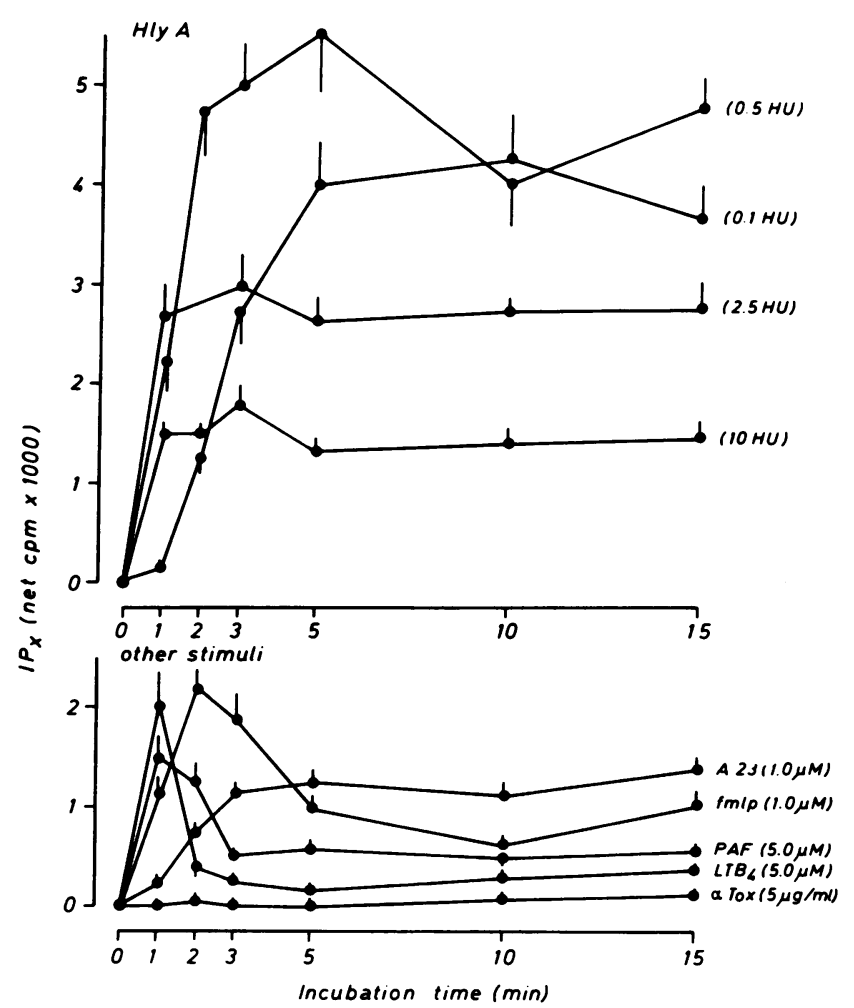

Figure 5. Time course of neutrophil inositol phosphate generation evoked by Hly in comparison with different other stimuli. $10^{7} \mathrm{PMN}$, prelabeled with $\left[{ }^{3} \mathrm{H}\right]$ inositol, were incubated with different concentrations of Hly (top) or different other stimuli at optimum concentrations (bottom) for various time periods. Extracted inositol phosphates were separated by anion-exchange chromatography. $\mathrm{IP}_{3}, \mathrm{IP}_{2}$, and $\mathrm{IP}_{1}$ are composed as $\mathrm{IP}_{x}$, corrected for baseline levels in nonchallenged PMN (net cpm; baseline range between 540 and $1,100 \mathrm{cpm}$ ).

Means \pm SEM of five (top) and four (bottom) independent experiments are given.

WEB 2086 and the 5-lipoxygenase inhibitor L-663-536 suppressed neither elastase and $\mathrm{O}_{2}^{-}$release nor inositol phosphate accumulation. Pretreatment ("priming") of neutrophils with a nonactivating concentration of PMA ( $3 \mathrm{nM})$ for 5 min augmented superoxide generation in response to a subsequent Hly challenge $(0.1 \mathrm{HU} / \mathrm{ml})$ by about twofold, but reduced toxin-dependent elastase liberation and accumulation of inositol phosphates.

As reported previously, incubation of $\mathrm{Hly}$ at $37^{\circ} \mathrm{C}$ resulted in rapid loss of its toxic properties (Fig. 9). As expected, the activity of FMLP remained unchanged under the same conditions.

In contrast to Hly, treatment of PMN with $0.1-50 \mu \mathrm{g} / \mathrm{ml}$ staphylococcal $\alpha$-toxin was virtually ineffective with regard to PtdIns hydrolysis and secretory responses (data for $5 \mu \mathrm{g} / \mathrm{ml}$ given in Figs. 1, 2, and 5), despite the fact that cytolytic activity became apparent above $5-10 \mu \mathrm{g} / \mathrm{ml}$.

\section{Discussion}

This study corroborates data of a previous report in showing that Hly is a potent inductor of neutrophil granule secretion (20). Virtually complete secretion of the total cellular elastase

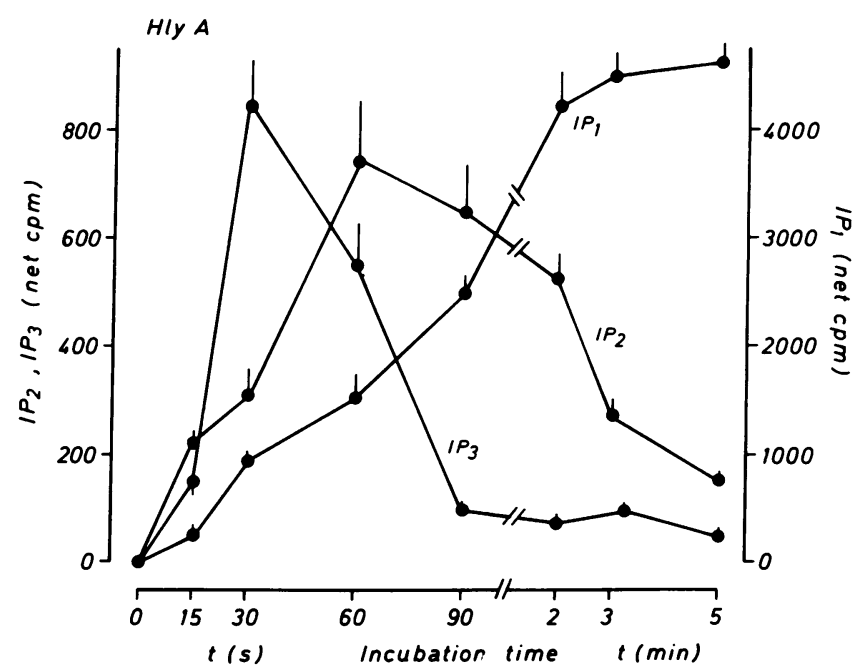

Figure 6. Sequential appearance of inositol phosphates in Hly-challenged neutrophils. $10^{7} \mathrm{PMN}$, prelabeled with $\left[{ }^{3} \mathrm{H}\right]$ inositol, were incubated with $0.1 \mathrm{HU} / \mathrm{ml}$ Hly for various time periods. Extracted inositol phosphates were sequentially eluted from anion-exchange columns and corrected for baseline levels in nonchallenged PMN (net cpm; baseline $\left[{ }^{3} \mathrm{H}\right] \mathrm{IP}_{3}=173 \pm 24 \mathrm{cpm},\left[{ }^{3} \mathrm{H}\right] \mathrm{IP}_{2}=259 \pm 19 \mathrm{cpm},\left[{ }^{3} \mathrm{H}\right] \mathrm{IP}{ }_{1}$ $=814 \pm 65 \mathrm{cpm})$. Means \pm SEM of five independent experiments are given.

and myeloperoxidase content was evoked by toxin concentrations in the range of 0.5 to $>2.5 \mathrm{HU} / \mathrm{ml}$. In addition to this secretory response, the present communication describes the previously undetected occurrence of marked PtdIns hydrolysis in neutrophils exposed to low Hly doses (optimum concentration range $\approx 0.1-0.5 \mathrm{HU} / \mathrm{ml}$ ). This triggering of a preformed PMN stimulus transmission pathway was paralleled by metabolic responses including the formation of PAF and lyso-PAF, the generation of superoxide anion, and the synthesis and re-

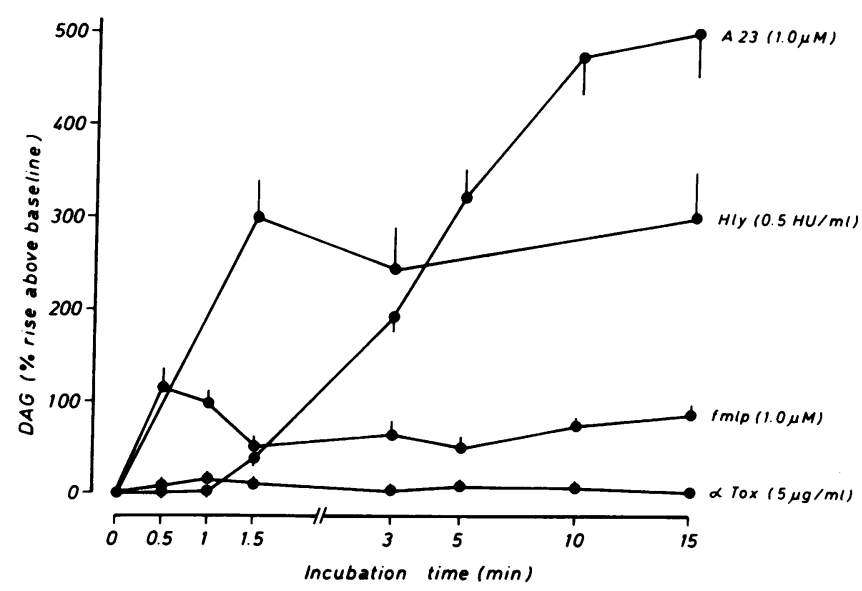

Figure 7. Time course of neutrophil DAG generation evoked by Hly in comparison with different other stimuli. $10^{7} \mathrm{PMN}$ were incubated with Hly or different other stimuli at optimum concentrations for various time periods. DAG formation is expressed as percent above baseline values, detected in sham-challenged PMN studied in parallel (baseline range $154.2 \pm 24 \mathrm{pmol} / 10^{7} \mathrm{PMN}$ ). Means \pm SEM of four independent experiments are given. 


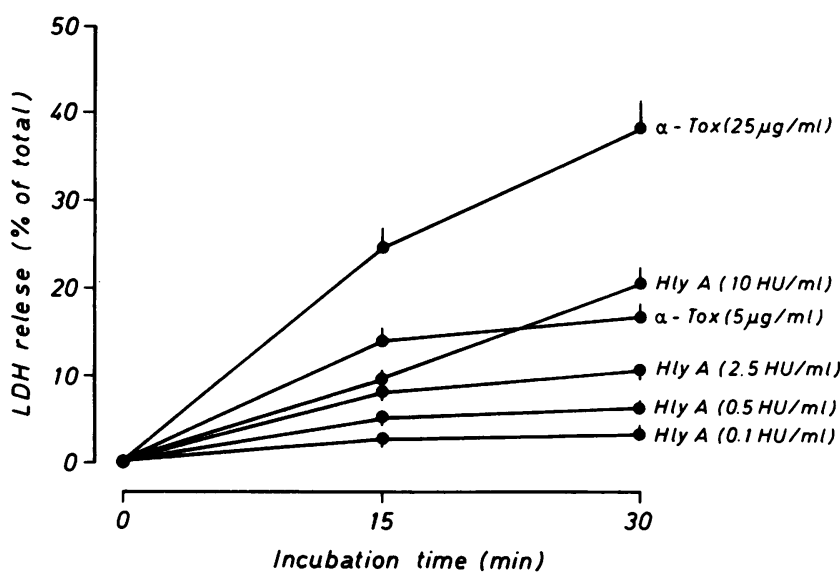

Figure 8. Time course of neutrophil LDH release evoked by Hly in comparison with staphylococcal $\alpha$-toxin (Tox). $10^{7}$ PMN were incubated with different concentrations of Hly or $\alpha$-toxin up to $30 \mathrm{~min}$. LDH release is expressed as percentage of total cellular enzyme content. Means \pm SEM of five independent experiments are given.

lease of leukotrienes (27). The ability of Hly to stimulate respiratory burst was previously observed in PMN (25) and renal tubular cells (47) upon use of low toxin concentrations, whereas it was missed in experiments employing overtly cytocidal toxin doses (20). This discrepancy is evidently explained by the presently noted unusual bell-shaped dose dependency of
PtdIns hydrolysis and related metabolic responses. This doseeffect curve suggests predominance of signal transduction events at low Hly concentrations, in contrast to predominant cytolysis at high toxin doses. Neutrophils permeabilized owing to high toxin load (20) evidently fail to respond metabolically in terms of PtdIns hydrolysis and mediator release, most probably due to breakdown of cell homeostasis.

In Hly-treated PMN, inositol phosphate formation was detectable within $1 \mathrm{~min}$, similar to the onset of signal transduction in PMN activated by ligand-receptor interaction (FMLP, PAF, LTB $_{4}$ ). The kinetics of sequential $\mathrm{IP}_{3}$ and $\mathrm{IP}_{2}$ appearance with subsequent accumulation of $\mathrm{IP}_{1}$ and the concomitant formation of DAG were compatible with an activation of PtdInsdiphosphate-specific phospholipase $\mathrm{C}$, which is operative in neutrophil stimulus response coupling (28-32). Several lines of evidence indicated that the metabolic responses observed in PMN exposed to subcytolytic Hly doses were mediated via PtdIns hydrolysis-related signal transduction pathways. First, all presently assessed PMN reactions are known to occur upon stimulation of this pathway, via DAG-mediated protein kinase $\mathrm{C}$ activation and/or inositol phosphate-related calcium fluxes (28-32). Second, inositol phosphate formation, respiratory burst, PAF generation, and leukotriene synthesis (27) all displayed corresponding bell-shaped dose dependencies with optimum toxin-efficacy at $\approx 0.1-0.5 \mathrm{HU} / \mathrm{ml}$. Granule secretion (elastase, myeloperoxidase) already commenced at this low dose range, but additionally progressed at higher Hly concentrations that elicited rapid membrane permeabilization $(\approx 2.5$

Table I. Pertussis Toxin Sensitivity of Hly-and Receptor-operated PMN Stimluation*

\begin{tabular}{|c|c|c|c|c|c|}
\hline \multirow[b]{2}{*}{ Stimulus } & & \multicolumn{2}{|c|}{ Elastase } & \multicolumn{2}{|c|}{$\mathbf{I P}_{\boldsymbol{x}}$} \\
\hline & & $-\mathrm{PT}$ & $+\mathrm{PT}$ & $-\mathrm{PT}$ & $+\mathrm{PT}$ \\
\hline & & \multicolumn{2}{|c|}{ \% total } & \multicolumn{2}{|c|}{ net cpm } \\
\hline \multirow{3}{*}{$\mathrm{Hly}^{\ddagger}(H U / m l)$} & 0.1 & $39.4 \pm 5.3$ & $9.2 \pm 0.8$ & $3,898 \pm 459$ & $2,121 \pm 189$ \\
\hline & 0.5 & $66.8 \pm 7.0$ & $28.5 \pm 3.1$ & $5,347 \pm 668$ & $2,879 \pm 314$ \\
\hline & 2.5 & $95.3 \pm 4.2$ & $57.8 \pm 5.4$ & $2,504 \pm 238$ & $1,811 \pm 158$ \\
\hline \multirow{3}{*}{ FMLP $(\mu M)$} & 0.01 & $12.4 \pm 1.3$ & $3.8 \pm 0.3$ & $962 \pm 84$ & $213 \pm 20$ \\
\hline & 0.1 & $18.5 \pm 1.4$ & $5.8 \pm 0.4$ & $1,837 \pm 191$ & $424 \pm 38$ \\
\hline & 1.0 & $25.6 \pm 2.0$ & $9.2 \pm 0.8$ & $1,984 \pm 224$ & $745 \pm 69$ \\
\hline \multirow{3}{*}{$\operatorname{PAF}(\mu M)$} & 0.1 & $8.9 \pm 0.4$ & $<3$ & $381 \pm 29$ & $<50$ \\
\hline & 1.0 & $11.4 \pm 0.7$ & $6.6 \pm 0.7$ & $1,478 \pm 156$ & $533 \pm 71$ \\
\hline & 5.0 & $18.1 \pm 1.2$ & $16.4 \pm 1.4$ & $1,314 \pm 104$ & $971 \pm 64$ \\
\hline \multirow{3}{*}{$\mathrm{LTB}_{4}(\mu M)$} & 0.1 & $6.8 \pm 0.4$ & $<3$ & $289 \pm 25$ & $<50$ \\
\hline & 1.0 & $10.6 \pm 0.8$ & $<3$ & $1,977 \pm 210$ & $549 \pm 61$ \\
\hline & 5.0 & $15.7 \pm 1.0$ & $6.2 \pm 0.5$ & $1,637 \pm 144$ & $803 \pm 92$ \\
\hline \multirow{2}{*}{ A $23187(\mu M)$} & 1.0 & $56.7 \pm 4.5$ & $50.9 \pm 5.1$ & $1,223 \pm 95$ & $1,092 \pm 82$ \\
\hline & 5.0 & $62.9 \pm 4.8$ & $64.8 \pm 5.6$ & $1,024 \pm 71$ & $981 \pm 73$ \\
\hline
\end{tabular}

* $10^{7} \mathrm{PMN}$, preincubated with and without $1.0 \mu \mathrm{g} / \mathrm{ml}$ PT for $2.0 \mathrm{~h}$ were used in all experiments. Elastase was measured $15 \mathrm{~min}$ after application of the different stimuli and is given as percentage of total cellular enzyme content. $\mathrm{IP}_{3}, \mathrm{IP}_{2}$, and $\mathrm{IP}_{1}$ were quantified at times of maximum responses to the different stimuli and are composed as $\mathrm{IP}_{x}\left(1 \mathrm{~min}\right.$ after $\mathrm{LTB}_{4}$ and $\mathrm{PAF}$ application, $2 \mathrm{~min}$ after FMLP stimulation, and 5 min after Hly and A23187 challenge; values given as net counts per minute according to Fig. 5). Means \pm SEM of six independent experiments each are given.

* At all Hly concentrations, elastase release and $\mathrm{IP}_{x}$ generation in the presence of PT differed significantly from those in the absence of PT $(P$ $<0.01$; two-tailed $t$ test for unpaired samples). 
$\mathrm{HU} / \mathrm{ml}$ ). Third, the inositol phosphate accumulation evoked by Hly exceeded that observed in response to the chemoattractive ligands FMLP, PAF, and $\mathrm{LTB}_{4}$ (all used at optimum concentrations) by greater than fourfold. Correspondingly, the hemolysin was markedly more efficient than these agents in eliciting degranulation, arachidonic acid 5-lipoxygenase metabolism (27), and PAF formation (data for the ligands not given in detail). Superoxide generation evoked by Hly ranged somewhat below that elicited by optimum doses of FMLP, despite the higher DAG concentrations generated in the presence of the hemolysin. This finding is reminiscent of the decrease in $\mathrm{O}_{2}^{-}$ generation observed in PMN in the presence of high ionomycin concentrations in spite of increased DAG levels, and might possibly be explained by a sensitivity of the DAG-activated NADPH oxidase complex to membrane perturbation and/or excessively high intracellular calcium concentrations (48). Fourth, pretreatment with PT suppressed both Hly-evoked PtdIns hydrolysis and the PMN metabolic and secretory responses. Moreover, the response to Hly after PMA pretreatment was modulated according to the previously described concept of PMA "priming" for ligand-operated stimulation in neutrophils $(49,50)$. Finally, H7 selectively blocked the Hlyevoked superoxide generation, as anticipated for a protein kinase C-dependent toxin mechanism. Inhibition of leukotriene and 5-hydroxyeicosatetraenoic acid generation as well as use of a specific PAF antagonist did not affect the Hly-induced inositol phosphate release. Secondary loops of autocrine PMN activation due to generation of these lipid mediators $(51,52)$ can

Table II. Influence of Different Experimental Agents on Hlyinduced PMN Stimulation*

\begin{tabular}{lccc}
\hline & Elastase & $\mathrm{O}_{2-}$ & $\mathrm{IP}_{x}$ \\
\hline & \% total & $n m o l / 5 \times 10^{7}$ cells & net cpm \\
Hly & $66.8 \pm 4.2$ & $72.4 \pm 10.2$ & $5,504 \pm 676$ \\
$\begin{array}{c}\text { Hly }+\mathrm{H} 7 \\
(25 \mu \mathrm{M})\end{array}$ & $69.3 \pm 6.9$ & $31.6^{\prime \prime} \pm 4.4$ & $5,811 \pm 588$ \\
$\begin{array}{l}\text { Hly }+ \text { WEB } \\
(1 \mu \mathrm{M})\end{array}$ & $72.5 \pm 7.2$ & $68.4 \pm 9.2$ & $5,439 \pm 614$ \\
$\begin{array}{l}\text { Hly }+ \text { L663-536 } \\
(1 \mu \mathrm{M})\end{array}$ & $63.4 \pm 4.1$ & $74.0 \pm 6.6$ & $5,364 \pm 618$ \\
$\begin{array}{c}\text { Hly after } \\
\text { PMA priming }\end{array}$ & $51.6^{\prime \prime} \pm 5.3$ & $138.4^{\prime \prime} \pm 11.6$ & $4,112^{\prime \prime} \pm 442$
\end{tabular}

* $10^{7} \mathrm{PMN}$ were incubated with $0.5 \mathrm{HU} / \mathrm{ml} \mathrm{Hly}$ (measurement of elastase and $\mathrm{IP}_{x}$ ) and $5 \times 10^{6} \mathrm{PMN}$ with $0.1 \mathrm{HU} / \mathrm{ml}$ (superoxide generation) in the absence or presence of different experimental agents. All agents were preincubated for $3 \mathrm{~min}$. Inositol phosphates (IP $\left.\mathbf{P}_{x}\right)$ were quantified $5 \mathrm{~min}$, and elastase and superoxide $15 \mathrm{~min}$ after neutrophil stimulation. Means \pm SEM of four or five independent experiments each are given.

${ }^{\ddagger}$ In the presence of the 5-lipoxygenase inhibitor L 663-536, the Hlyinduced $\mathrm{LTB}_{4}$ and 5-hydroxyeicosatetraenoic acid generation was inhibited by $>90 \%$.

${ }^{3}$ Cells were incubated with PMA ( $3 \mathrm{nM}$ ) for 3 min before challenge with $0.1 \mathrm{HU} / \mathrm{ml} \mathrm{Hly} \mathrm{(measurement} \mathrm{of} \mathrm{superoxide)} \mathrm{or} 0.5 \mathrm{HU} / \mathrm{ml}$ Hly (measurement of elastase and $\mathrm{IP}_{\boldsymbol{x}}$ ).

" $P<0.01$ (two-tailed $t$ test for unpaired samples obtained in the absence and presence of experimental agent).

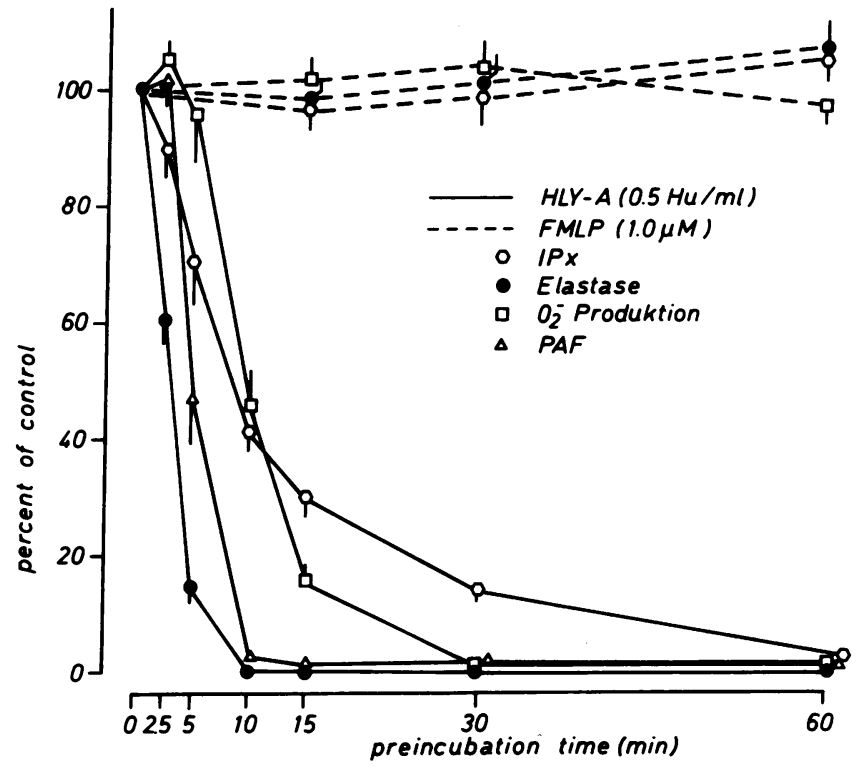

Figure 9. Loss of Hly activity upon incubation at $37^{\circ} \mathrm{C}$. Before application to $10^{7} \mathrm{PMN}$, Hly was incubated at $37^{\circ} \mathrm{C}$ for various time periods. $\mathrm{IP}_{x}$ was measured at $5 \mathrm{~min}, \mathrm{PAF}$ at $10 \mathrm{~min}$, and superoxide and elastase at $15 \mathrm{~min}$ after stimulus application. All data are given as percentage of control values obtained from parallel experiments with fully active Hly. In contrast to the rapid "aging" of Hly at $37^{\circ} \mathrm{C}$, no significant decrease in activity was observed upon preincubation of FMLP (used at 0.1 [data not given] and $1 \mu \mathrm{M}$ ). All values represent mean \pm SEM of four independent experiments.

thus be excluded as major contributing events under the presently studied conditions. Thus, initiation of the PtdIns hydrolysis-related stimulus transmission pathway appears to be the predominant underlying mechanism, triggering metabolic and secretory PMN responses to Hly in subcytolytic concentrations.

There is compelling evidence that the PMN activation was evoked by the bacterial exotoxin itself and not by contaminating LPS. A toxin preparation with markedly depleted endotoxin content was used (residual contamination amounting only to $\approx 3 \mathrm{ng}$ of LPS/ $\mu$ g protein). Rapid loss of toxin activity occurred upon "aging" of the preparation at $37^{\circ} \mathrm{C}$, a feature repeatedly described for the hemolysin, but not compatible with established endotoxin characteristics $(20,21)$. Preincubation of PMN with endotoxin is known to exert "priming" effects in these cells, but direct initiation of acute secretory responses has not been described (53-56). Accordingly, no PMN responses were evoked upon use of $E$. coli endotoxin up to 100 $\mathrm{ng} / \mathrm{ml}$ within the stimulation periods of the present study (data not given in detail). However, these findings do not exclude cooperative interaction of remaining LPS molecules and Hly peptides in eliciting metabolic and secretory responses in the neutrophils.

How is the hemolysin effect linked with the initiation of PMN PtdIns turnover and second messenger induction? Poreforming bacterial agents certainly evoke a variety of cellular responses via facilitation of passive calcium flux into the cells (19, 57-61). However, optimal concentrations of the calcium ionophore A23187 induce only moderate and delayed-onset inositol phosphate formation in neutrophils, which may actu- 
ally be due to the marked generation of $\mathrm{LTB}_{4}$ and PAF with secondary (autocrine) PMN activation. Moreover, staphylococcal $\alpha$-toxin induces transmembrane calcium flux in neutrophils (60), but does not evoke any significant PtdIns turnover in these cells. It has previously been noted that inositol phosphate formation by PIP $_{2}$ - and PIP-specific phospholipase $\mathrm{C}$ is independent of cytoplasmatic $\mathrm{Ca}^{++}$elevation (62-64). Thus, it is presently unclear whether Hly-elicited transmembrane calcium flux is involved in triggering the described metabolic responses. The significant PT sensitivity of PtdIns turnover and related metabolic and secretory responses may indicate enrollment of G proteins in Hly-evoked PMN stimulation (51, 65$66)$. Cell surface receptors for Hly have hitherto not been characterized, and further experimental approaches are necessary to delineate the molecular mechanisms by which this bacterial exotoxin triggers key events of PMN regulation with outstandingly strong potency.

\section{Acknowledgments}

This work was supported by the Deutsche Forschungsgemeinschaft (Klinische Forschergruppe "Respiratorische Insuffizienz" and SFB grant 311).

\section{References}

1. Cavalieri, S. J., G. A. Bohach, and I. S. Snyder. 1984. Escherichia coli $\alpha$-hemolysin: characteristics and probable role in pathogenicity. Microbiol. Rev. 48:326-343.

2. Bhakdi, S., N. Mackman, J.-M. Nicaud, and I. B. Holland. 1986. Escherichia coli hemolysin may damage target cell membranes by generating transmembrane pores. Infect. Immun. 52:63-69.

3. Bhakdi, S., and J. Tranum-Jensen. 1987. Damage to mammalian cells by proteins that form transmembrane pores. Rev. Physiol. Biochem. Pharmacol. 107:148-223.

4. Bhakdi, S., and J. Tranum-Jensen. 1988. Damage to cell membranes by pore-forming bacterial cytolysins. Prog. Allergy. 40:1-43.

5. Mackman, N., and I. B. Holland. 1984. Secretion of a $107 \mathrm{~K}$ dalton polypeptide into the medium from a hemolytic $E$. coli $\mathrm{K} 12$ strain. Mol. Gen. Genet. 193:312-315.

6. Welch, R. A., and S. Pellet. 1988. Transcriptional organization of the Escherichia coli hemolysin genes. J. Bacteriol. 170:1622-1630.

7. Welch, R. A., E. P. Dellinger, B. Minshew, and S. Falkow. 1981. Hemolysin contributes to virulence of extra-intensital $E$. coli infections. Nature (Lond.). 294:665-667.

8. Welch, R. A., and S. Falkow. 1984. Characterization of Escherichia coli hemolysin conferring quantitative differences in virulence. Infect. Immun. 43:156-160.

9. Fünfstück, R., H. Tschäpe, G. Stein, H. Kunath, M. Bergner, and G. Wessel. 1986. Virulence properties of Escherichia coli strains in patients with chronic pyelonephritis. Infection. 14:145-150.

10. Hacker, J., C. Hughes, H. Hof, and W. Goebel. 1983. Cloned hemolysin genes from Escherichia coli that cause urinary tract infection determine different levels of toxicity in mice. Infect. Immun. 42:57-63.

11. Felmlee, T., S. Pellet, and R. A. Welch. 1985. Neucleotide sequence of an E. coli chromosomal hemolysin. J. Bacteriol. 163:94-105.

12. Strathdee, C. A., and R. Y. Lo. 1987. Extensive homology between the leukotoxin of Pateurella haemolytica A1 and the alpha-hemolysin of Escherichia coli. Infect. Immun. 55:3233-3236.

13. Koronakis, V., M. Cross, B. Senior, E. Koronakis, and C. Hughes. 1987. The secreted hemolysins of Proteus mirabilis, Proteus vulgaris, and Morganella morganii are genetically related to each other and to the alpha-hemolysin of Escherichia coli. J. Bacteriol. 169:1509-1515.

14. Lo, R. Y., C. A. Strathdee, and P. E. Shewen. 1987. Nucleotide sequence of the leukotoxin genes of Pateurella haemolytica A1. Infect. Immun. 55:19871996.

15. Welch, R. A. 1987. Identification of two different hemolysin determinants in the uropathogenic Proteus isolates. Infect. Immun. 55:2183-2190.

16. Eberspächer, B., F. Hugo, M. Pohl, and S. Bhakdi. 1990. Functional similarity between the haemolysins of Escherichia coli and Morganella morganii. J. Med. Microbiol. 33:165-170.

17. Menestrina, G., N. Mackman, I. B. Holland, and S. Bhakdi. 1987. E. coli hemolysin forms voltage-dependent ion channels in lipid membranes. Biochim. Biophys. Acta. 905:109-117.

19. Suttorp, N., B. Flöer, H. Schnittler, W. Seeger, and S. Bhakdi. 1990. Effects of $E$. coli hemolysin on endothelial cell function. Infect. Immun. 58:37963801 .

20. Bhakdi, S., S. Greulich, M. Muhly, B. Eberspächer, H. Becker, A. Thiele, and F. Hugo. 1989. Potent leucocidal action of Escherichia coli hemolysin mediated by permeabilization of target cell membranes. J. Exp. Med. 169:737-754.

21. Bhakdi, S., M. Muhly, S. Korom, and G. Schmidt. 1990. Effects of $E$. coli hemolysin on human monocytes: cytocidal action and stimulation of interleukin1 release. J. Clin. Invest. In press.

22. Boehm, D. F., R. A. Welch, and I. S. Snyder. 1990. Calcium is required for binding of Escherichia coli hemolysin (Hlya) to erythrocyte membrane. Infect. Immun. 58:1951-1958.

23. Ludwig, A., T. Jarchau, R. Benz, and W. Goebel. 1988. The repeat domain of $E$. coli hemolysin is responsible for its Ca-dependent binding to erythrocytes. Mol. Gen. Genet. 214:553-561.

24. Boehm, D. F., R. A. Welch, and I. S. Snyder. 1990. Domains of Eschemain of $E$. coli hemolysin is responsible for its $\mathrm{Ca}$-dependent binding to erythrocytes. Mol. Gen. Genet. 214:553-561.

24. Boehm, D. F., R. A. Welch, and I. S. Snyder. 1990. Domains of Escherichia coli hemolysin (HlyA) involved in binding of calcium and erythrocyte membranes. Infect. Immun. 58:1959-1964.

25. Cavalieri, S. J., and I. S. Snyder. 1982. Effect of Escherichia coli alpha-hemolysin on human peripheral leukocyte function in vitro. Infect. Immun. 37:966-974.

26. Gadeberg, O. V., I. Orskov, and J. M. Rhodes. 1983. Cytotoxic effect of an alpha-hemolytic Escherichia coli strain on human blood monocytes and granulocytes in vitro. Infect. Immun. 41:358-364.

27. Grimminger, F., C. Scholz, S. Bhakdi, and W. Seeger. 1991. Subhemolytic doses of Escherichia coli hemolysin evoke large quantities of 4- and 5-series leukotrienes in human neutrophils in dependence on exogenous fatty acid supply. J. Biol. Chem. In press.

28. Omann, G. M., R. A. Allen, G. M. Bokoch, R. G. Painter, A. E. Traynor, and L. A. Sklar. 1987. Signal transduction and cytoskeletal activation in the neutrophil. Physiol. Rev. 67:285-313.

29. Alkon, D. L., and H. Rasmussen. 1988. A spatial-temporal model of cell activation. Science (Wash. DC). 239:998-1005.

30. Majerus, P. W., T. N. Connolly, V. S. Bansal, R. C. Inhorn, T. C. Ross, and D. L. Lips. 1988. Inositol phosphates: synthesis and degradation. J. Biol. Chem. 263:3051-3054.

31. Sandborg, T. T., and J. E. Smolen. 1988. Biology of disease. Early biochemical events in leukocyte activation. Lab. Invest. 59:300-310.

32. Rhee, S. G., P.-G. Suh, S.-H. Ryu, and S. Y. Lee. 1989. Studies of inositol phospholipid-specific phospholipase C. Science (Wash. DC). 244:546-550.

33. Grimminger, F., G. Becker, and W. Seeger. 1988. High yield enzymatic conversion of intravascular leukotriene A4 in blood-free perfused lungs. J. Immunol. 141:2431-2436.

34. Grimminger, F., B. Kreusler, U. Schneider, G. Becker, and W. Seeger. 1990. Influence of microvascular adherence on neutrophil leukotriene generation-evidence for sooperative eicosanoid synthesis. J. Immunol 144:1866-1872.

35. Seeger, W., N. Suttorp, A. Hellwig, and S. Bhakdi. 1986. Noncytolytic terminal complement complexes may serve as calcium gates to elicit leukotriene $B_{4}$ generation in human polymorphonuclear leukocytes. J. Immunol. 137:12861293.

36. Seeger, W., H. Walter, N. Suttorp, M. Muhly, and S. Bhakdi. 1989 Thromboxane-mediated hypertension and vascular leakage evoked by low doses of Escherichia coli hemolysin in rabbit lungs. J. Clin. Invest. 84:220-227.

37. Friberger, P. 1982. A quantitative endotoxin assay utilizing LAL and a chromogenic substrate. Prog. Clin. Biol. Res. 93:195-206.

38. Cohen, H. J., and M. E. Chovaniec. 1978. Superoxide generation by digitonin-stimulated guinea pig granulocytes. J. Clin. Invest. 61:1081-1087.

39. Henson, P. M. 1971. The immunologic release of constituents from neutrophil leukocytes. II. Mechanisms of release during phagocytosis, and adherence to non-phagocytosable surfaces. J. Immunol. 107:1547-1552.

40. Kramps, J. A. 1983. L-Pyroglutamyl-L-propyl-L-valine-p-nitro-anilide, a highly specific substrate for gramlocyte elastase. Scand. J. Clin. Lab. Invest. 43:427-432.

41. Chilton, F. H., J. M. Ellis, S. C. Olson, and R. L. Wykle. 1984. 1-O-alkyl-2arachidonoyl-sn-glycero-3 phosphocholine. J. Biol. Chem. 259:12014-12019.

42. Bligh, E. G., and W. J. Dyer. 1959. A rapid method of total lipid extraction and purification. Can. J. Biochem. Physiol. 37:753-757.

43. Tessner, T. G., J. T. O'Flaherty, and R. L. Wykle. 1989. Stimulation of platelet-activating factor synthesis by a nonmetabolizable bioactive analog of platelet-activating factor and influence of arachidonic acid metabolites. J. Biol. Chem. 264:4794-4799.

44. Pinckard, R. N., R. S. Farr, and D. J. Hanahan. 1979. Physico-chemical 
and functional identity of rabbit platelet-activating factor (PAF) released in vivo during IgE anaphylaxis with PAF released in vitro from IgE sensitized basophils. J. Immunol. 123:1847-1854.

45. Berridge, M. J., R. M. C. Dawson, C. P. Downes, J. P. Heslop, and R. F. Irvine. 1983. Changes in the levels of inositol phosphates after agonist-dependent hydrolysis of membrane phosphoinositides. Biochem. J. 212:473-482.

46. Preiss, J., C. R. Loomis, W. R. Bishop, R. Stein, J. E. Niedel, and R. M. Bell. 1985. Quantitative measurement of sn-1,2-diacylglycerols present in platelets, hepatocytes, and ras- and sis-transformed normal rat kidney cells. J. Biol. Chem. 261:8597-8600.

47. Keane, W. F., R. W. Welch, G. Gekker, and Ph. K. Peterson. 1987. Mechanism of Escherichia coli $\alpha$-hemolysin-induced injury to isolated renal tubular cells. Am. J. Pathol. 126:350-357.

48. Rider, L. G., and J. E. Niedel. 1987. Diacylglycerol accumulation and superoxide anion production in stimulated human neutrophils. J. Biol. Chem. 263:5603-5608.

49. Brock, T. A., S. E. Rittenhouse, C. W. Powers, L. S. Ekstein, M. A. Gimbrone, Jr., and R. W. Alexander. 1985. Phorbol ester and 1-oeyl-2-acetylglycerol inhibit angiotensin activation of phospholipase $C$ in cultured vascular smooth muscle cells. J. Biol. Chem. 260:14158-14162.

50. Tyagi, S. R., M. Tamura, D. N. Burnham, and J. D. Lambeth. 1988 Phorbol myristate acetate (PMA) augments chemoattractant-induced diglyceride generation in human neutrophils but inhibits phosphoinositide hydrolysis. $J$. Biol. Chem. 263:13191-13198.

51. Verghese, M. W., L. Charles, L. Jakoi, S. B. Dillon, and R. Snyderman 1986. Role of a guanine nucleotide regulatory protein in the activation of phospholipase $C$ by different chemoattractants. J. Immunol. 138:4374-4380.

52. Stewart, A. G., P. N. Dubbin, T. Harris, and G. J. Dusting. 1990. Plateletactivating factor may act as a second messenger in the release of icosanoids and superoxide anions from leukocytes and endothelial cells. Proc. Natl. Acad. Sci. USA. 87:3215-3219.

53. Aderem, A. A., D. S. Cohen, S. D. Wright, and Z. A. Cohn. 1986. Bacterial lipopolysaccharides prime macrophages for enhanced release of arachidonic acid metabolites. J. Exp. Med. 164:165-179.

54. Danner, R. L., K. A. Joiner, and J. E. Parrillo. 1987. Inhibition of endotoxin-induced priming of human neutrophils by lipid $\mathrm{X}$ and 3-Aza-lipid $\mathrm{X} . J$. Clin. Invest. 80:605-612.

55. Forehand, J. R., M. H. Pabst, W. A. Phillips, and R. B. Johnston, Jr. 1989. Lipopolysaccharide priming of human neutrophils for an enhanced respiratory burst. J. Clin. Invest. 83:74-83.
56. Doerfler, M. E., R. L. Danner, J. H. Shelhamer, and J. E. Parrillo. 1989. Bacterial lipopolysaccharides prime human neutrophils for enhanced production of leukotriene B4. J. Clin. Invest. 83:970-977.

57. Seeger, W., M. Bauer, and S. Bhakdi. 1984. Staphylococcal alpha-toxin elicits hypertension in isolated rabbit lungs: evidence for thromboxane formation and the role of extracellular calcium. J. Clin. Invest. 74:849-858.

58. Suttorp, N., W. Seeger, E. Dewein, S. Bhakdi, and L. Roka. 1985. Staphylococcal alpha-toxin induced PGI2 production in endothelial cells: role of calcium. Am. J. Physiol. 248:C127-C134.

59. Suttorp, N., W. Seeger, J. Uhl, F. Lutz, and L. Roka. 1985. Pseudomonas aeruginosa cytotoxin stimulates prostacyclin production in cultured pulmonary artery endothelial cells: membrane attack and calcium influx. J. Cell. Physiol. 123:64-72.

60. Suttorp, N., W. Seeger, J. Zucker-Reimann, L. Roka, and S. Bhakdi. 1987. Mechanism of leukotriene generation in polymorphonuclear leukocytes by staphylococcal alpha-toxin. Infect. Immun. 55:104-110.

61. Bhakdi, S., M. Muhly, U. Mannhardt, F. Hugo, K. Klapettek, C. MuellerEckhardt, and L. Roka. 1988. Staphylococcal $\alpha$-toxin promotes blood coagulation via attack on human platelets. J. Exp. Med. 168:527-543.

62. Dougherty, R. W., P. P. Godfrey, P. C. Hoyle, J. W. Putney, Jr., and R. J. Freer. 1984. Secretagogue-induced phosphoinositide metabolism in human leucocytes. Biochem. J. 222:307-314.

63. Ohta, H., F. Okajima, and M. Ui. 1985. Inhibition by islet-activating protein of a chemotactic peptide-induced early breakdown of inositol phospholipids and $\mathrm{Ca}^{2+}$ mobilization in guinea pig neutrophils. J. Biol. Chem. 260:15771-15780.

64. Di Virgilio, F., L. M. Vicentini, S. Treves, G. Riz, and T. Pozzan. 1985. Inositol phosphate formation in fMet-Leu-Phe-stimulated human neutrophils does not require an increase in the cytosolic free $\mathrm{Ca}^{2+}$ concentration. Biochem. J. 229:361-367.

65. Freissmuth, M., P. J. Casey, and A. G. Gilman. 1989. G proteins control diverse pathways of transmembrane signaling. FASEB (Fed. Am. Soc. Exp. Biol.) J. 3:2125-2131.

66. Gomez-Camcambronero, J., M. Durstin, T. F. P. Molski, P. H. Naccache, and R. I. Sha'afi. 1989. Calcium is necessary but not sufficient for the platelet-activating factor release in human neutrophils stimulated by physiological stimuli. J. Biol. Chem. 264:21699-21704.

67. Reisine, T. 1990. Pertussis toxin in the analysis of receptor mechanisms. Biochem. Pharmacol. 39:1499-1504. 